\title{
Composting paper and grass clippings with anaerobically treated palm oil mill effluent
}

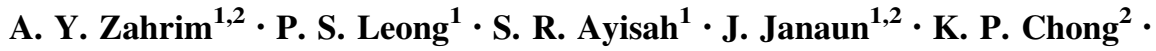 \\ F. M. Cooke $^{2} \cdot$ S. K. Haywood ${ }^{3}$
}

Received: 15 December 2015/Accepted: 7 June 2016/Published online: 16 June 2016

(c) The Author(s) 2016. This article is published with open access at Springerlink.com

\begin{abstract}
Purpose The purpose of this study is to investigate the composting performance of anaerobically treated palm oil mill effluent (AnPOME) mixed with paper and grass clippings.

Methods Composting was conducted using a laboratory scale system for 40 days. Several parameters were determined: temperature, mass reduction, $\mathrm{pH}$, electrical conductivity, colour, zeta potential, phytotoxicity and final compost nutrients.

Results The moisture content and compost mass were reduced by 24 and $18 \%$, respectively. Both final compost $\mathrm{pH}$ value and electrical conductivity were found to increase in value. Colour (measured as $\mathrm{PtCo}$ ) was not suitable as a maturity indicator. The negative zeta potential values decreased from -12.25 to $-21.80 \mathrm{mV}$. The phytotoxicity of the compost mixture was found to decrease in value during the process and the final nutrient value of the compost indicates its suitability as a soil conditioner.

Conclusions From this study, we conclude that the addition of paper and grass clippings can be a potential substrate to be composted with anaerobically treated palm oil mill effluent (AnPOME). The final compost produced is suitable for soil conditioner.
\end{abstract}

A. Y. Zahrim

zahrim@ums.edu.my

1 Chemical Engineering Programme, Faculty of Engineering, Universiti Malaysia Sabah, Jalan UMS, 88400 Kota Kinabalu, Sabah, Malaysia

2 Sustainable Palm Oil Research Unit, Universiti Malaysia Sabah, Jalan UMS, 88400 Kota Kinabalu, Sabah, Malaysia

3 School of Engineering, University of Hull, Cottingham Road, Hull HU6 7RX, UK
Keywords Composting · Paper - Grass · Anaerobic palm oil mill effluent $\cdot$ Phytotoxicity

\section{Introduction}

The large volume of palm oil mill effluent (POME) in Malaysia contributes a major source of pollution (Bala et al. 2014) and it is difficult to handle in effluent treatment plants especially during the rainy season. It was reported that about 60 million tonnes of POME were generated from 421 palm oil mills in Malaysia in the year 2010 (Tabassum et al. 2015). Most of the POME is treated through a series of anaerobic ponds followed by aerobic ponds. However, black-dark-brown coloured effluent is generated from the anaerobic ponds which is difficult to biodegrade at the subsequent aerobic ponds (Zahrim et al. 2014). The anaerobically treated POME or AnPOME consists of particulates $[0.32-0.39 \%(\mathrm{w} / \mathrm{w})]$ such as anaerobic microorganisms, bioflocs, and macrofibrils. The soluble fraction contains carbohydrates, pectin, lignin, tannin, humic and fulvic acid based substances, melanoidin and phenolic compounds (Zahrim 2014; Yaser et al. 2013).

There are several methods to treat AnPOME including membrane separation, advanced oxidation processes, ozonation, sonication, adsorption, ion exchange, coagulation/flocculation and biological treatment. Each treatment has their advantages and disadvantages (Zahrim 2014). Owing to the large volume of palm oil mill effluent, the treatment will be more efficient if the effluent loading rate can be reduced by recycling it as a substrate for the composting process and direct irrigation (Palaniappan 1993). Although, direct irrigation has the lowest operational cost, there is potential for leaching of nutrients into the soil over a long period of time, which could lead to an imbalance of 
nutrients for plant uptake (Palaniappan 1993). Composting is defined as an aerobic microbiological process that converts the organic substances of wastes into stabilized humus and less complex compounds (Xiao et al. 2009). The composting process is affected by many factors such as carbon to nitrogen ratio, moisture content, $\mathrm{pH}$ and aeration rate (Lim et al. 2016; Wu et al. 2014; Zahrim et al. 2015).

The issue of solid waste, such as paper and grass clippings is also becoming a challenging task for large metropolitan areas in most developing countries (Moh and Abd Manaf 2014). If this waste is not managed well, it will become a problem to the environment. Composting has been reported as a potential method for recycling paper and grass clippings (Ball et al. 2000; Francou et al. 2008; Juchelkova et al. 2015; Elouaqoudi et al. 2015). However, to the best of our knowledge, there is no published study on the composting of AnPOME mixed with paper and grass clippings, although these may offer complementary constituents e.g., in terms of nutrients and moisture content. Several studies have been conducted utilizing POME for composting with other materials e.g., (Zahrim et al. 2015). Recently, Hoe et al. (2016) evaluated the suitability of using POME-EFB compost as a carrier for nitrogen fixing bacteria (NFB) and phosphate solubilizing bacteria (PSB). In another study, Amira Dayana et al. (2011) showed the performance of Trichoderma virens as an activator for the conversion of empty fruit bunches (EFB) and palm oil mill effluent (POME) into compost. The authors reported that the $\mathrm{N}, \mathrm{P}$ and $\mathrm{K}$ content of compost with $T$. virens increased significantly after maturation which was $1.304,0.5034$ and $0.645 \%$, respectively (Amira Dayana et al. 2011).

To obtain an efficient composting process, the influencing factors must be controlled and optimized. In this study, the AnPOME is utilized as a nutrient source and moisturizing agent for grass clippings-paper mixture. The performance of the process was evaluated based on temperature due to heat profiles, moisture content, mass reduction, $\mathrm{pH}$ level, electrical conductivity, colour, zeta potential and phytotoxicity.

\section{Methods}

A composting study was established at the Environmental Lab, Faculty of Engineering (FKJ), Universiti Malaysia Sabah which is located at Sabah, Malaysia. The study was conducted over a period of 40 days. A laboratory-scale composting system was used for this study (Figs. 1, 2). A plastic box with lid was used as the bioreactor with a dimension of $35.7 \mathrm{~cm} \times 28.8 \mathrm{~cm} \times 48 \mathrm{~cm}$. The design of this bioreactor was inspired by our previous study (Yaser
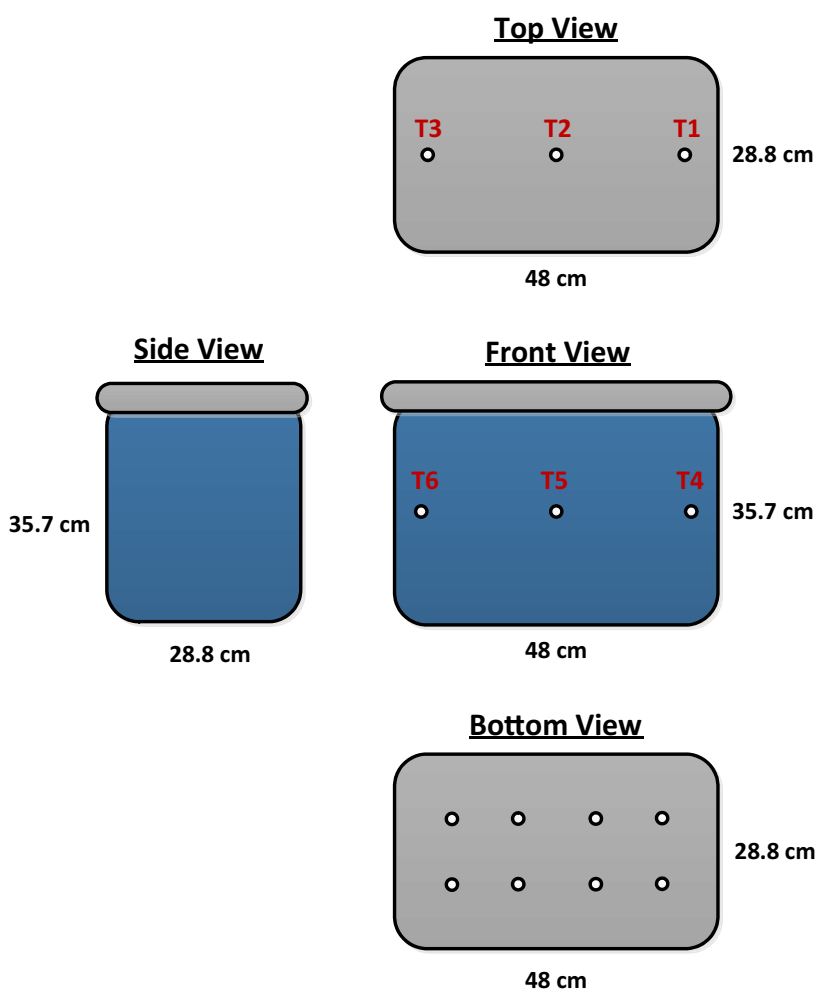

Fig. 1 Bioreactor design

et al. 2007). From our perspective, the small bioreactor is easy to maintain i.e., less waste required and easy to control with low capital cost. The bioreactor was placed on two bricks and there were eight holes $(1 \mathrm{~cm}$ diameter) at the bottom of the reactor to provide air into the reactor. A multipurpose tray was placed under the bioreactor so that cleanliness of the floor could be maintained. There were three holes $(1 \mathrm{~cm}$ diameter) in the reactor lids and three holes $(1 \mathrm{~cm}$ diameter) at the side of the reactor for inducing passive aeration. Two reactors were run simultaneously.

\section{Materials}

About $2.4 \mathrm{~kg}$ of paper, $3.6 \mathrm{~kg}$ of grass, $1.8 \mathrm{~kg}$ of anaerobically treated palm oil mill effluent (AnPOME) and $1 \mathrm{~kg}$ of recycled compost were used as the experimental material in the composting process. These figures were obtained from the moisture balance analysis for the initial compost mixture. Paper used in the experiment was collected from the Faculty of Engineering (FKJ) office, University Malaysia Sabah and was shredded. Fresh grass was collected from house gardens in Kingfisher residential area. Recycled kitchen waste compost was supplied by a local house waste composter in Taman Indah Permai residential 
Fig. 2 Diagram of the bioreactor in laboratory-scale composting system
Side View

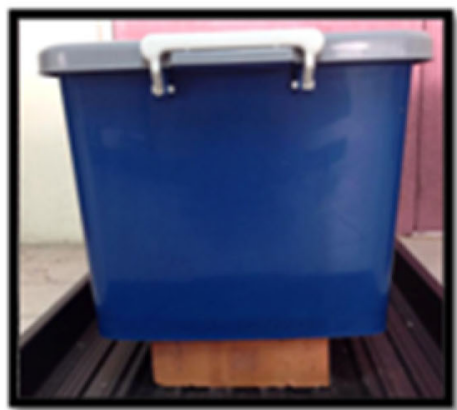

Top View

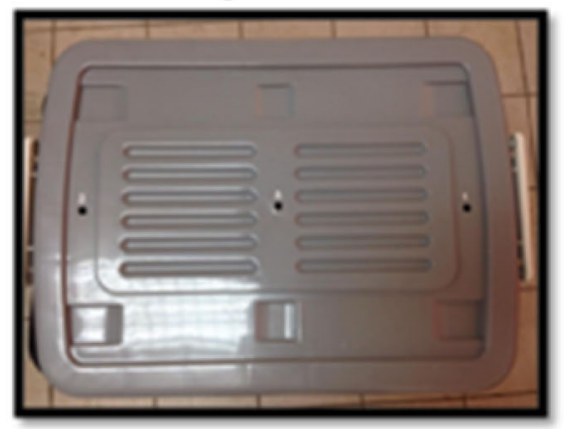

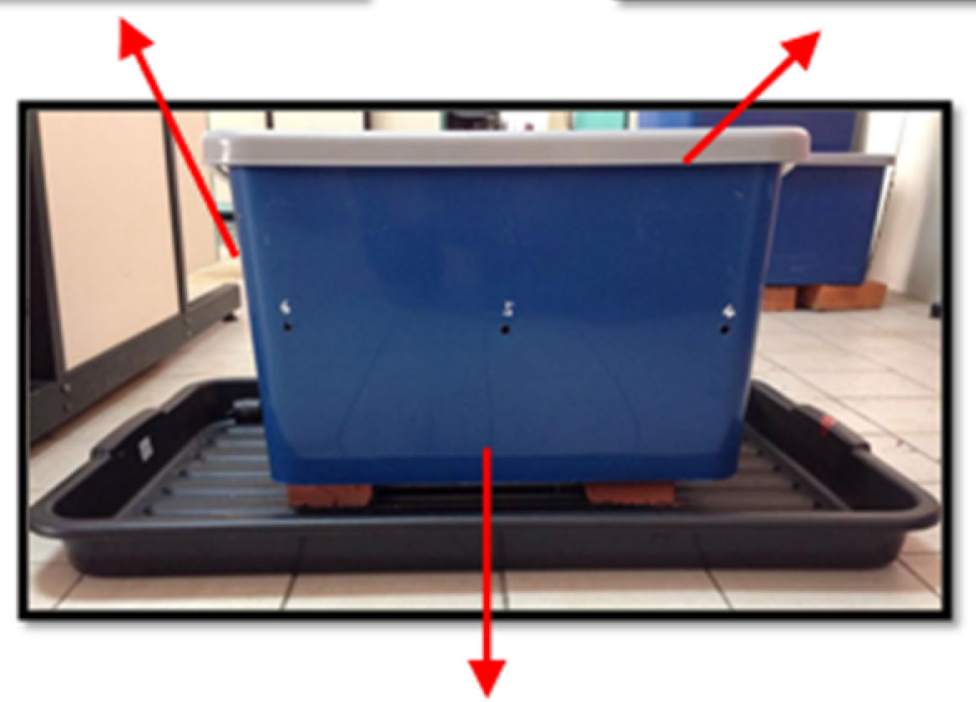

Bottom View

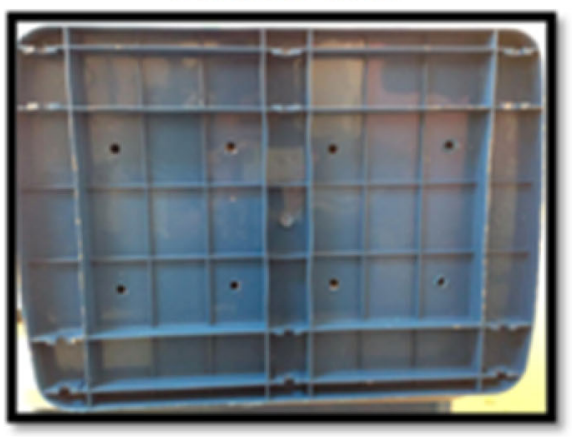

area to facilitate the composting process (Yaser et al. 2007). Normally, the kitchen compost has the following characteristics (Baishya et al. 2016): pH 07.6; N $0.198 \%$; $\mathrm{P} 0.212 \%$; K $0.399 \%$; Na $0.253 \%$; C/N 26. The AnPOME was collected from Sawit Kinabalu Kilang Lumadan, in Beaufort. AnPOME was used as a nutrient source and moisturizer for the composting process. The composting materials were manually mixed in the reactor to achieve better homogenization of material. Table 1 shows that the characteristics of the composting materials including moisture content, total organic carbon, total nitrogen, $\mathrm{pH}$ and electrical conductivity.

\section{Sampling}

The samples were taken from different places in the composting materials (top, middle, and bottom) after mixing. The analysis of the fresh samples was performed immediately after taking them out of the reactor; otherwise the sample would be covered by plastic and stored in the refrigerator. The collected samples that were not immediately analyzed from each time period were stored at $-4{ }^{\circ} \mathrm{C}$ until required for analysis of moisture content, total organic carbon, total nitrogen, $\mathrm{pH}$, electric conductivity and phytotoxicity. For the whole sampling procedure, the total 
Table 1 Characteristics of the composting materials

\begin{tabular}{|c|c|c|c|c|c|}
\hline $\begin{array}{l}\text { Characteristics of } \\
\text { materials }\end{array}$ & $\begin{array}{l}\text { Moisture } \\
\text { content }(\%)\end{array}$ & Total organic carbon $(\%)$ & Total nitrogen $(\%)$ & $\mathrm{pH}$ & 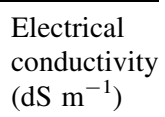 \\
\hline Paper & 8 & 41.4, Siang and Zakaria (2006) & 0.11, Siang and Zakaria (2006) & 6.9 & 0.13 \\
\hline Grass & 71.38 & 18.4, Traversa et al. (2014) & 1.56, Traversa et al. (2014) & 5.8 & 0.54 \\
\hline $\begin{array}{l}\text { Anaerobic palm } \\
\text { oil mill effluent }\end{array}$ & - & $100^{\mathrm{a}}$, Zahrim et al. (2014) & $200^{\mathrm{b}}$, Zahrim et al. (2014) & 7.0 & 3.03 \\
\hline
\end{tabular}

${ }^{a}$ Chemical oxygen demand (COD), $\mathrm{mg} / \mathrm{L}$

b Ammonia nitrogen, mg/L

mass of samples taken was less than $5 \%$ of the total mass of the mixture.

\section{Physicochemical analysis}

Temperature of the compost and ambient temperature were measured daily over the period of 40 days. A digital thermometer was inserted into the six holes of the reactor to measure the temperature of compost [T1, T2, T3, T4, T5, and T6) at six different places (refer to Fig. 2)]. The ambient temperature was also determined using the digital thermometer and recorded.

$20 \mathrm{~g}$ of sample was taken to measure the moisture content on days $0,10,20,30$ and 40 . The moisture content of the mixture was determined by the dry oven method at $105^{\circ} \mathrm{C}$ for $24 \mathrm{~h}$ (Petric et al. 2012). The initial mass and final mass of the mixture were recorded. The moisture content of the mixture was calculated by using the following formula:

Moisture content $(\%)=\frac{\text { Initial mass }- \text { final mass }}{\text { Initial mass }}$

The mass reduction was measured on days $0,10,20,30$ and 40. The mass reduction of each compost sample was calculated as the difference between the original mass and the mass at each sampling time, accounting for any removal from previous samplings. The $\mathrm{pH}$ and electric conductivity of the mixture were determined on days $0,10,20,30$ and 40. $10 \mathrm{~g}$ sample was added to $100 \mathrm{~mL}$ distilled water, mixed with magnetic stirrer for $20 \mathrm{~min}$, allowed to stand for $24 \mathrm{~h}$ and then filtered. The solution was analyzed using a pH/conductivity meter (HI9811-5, Hanna Instrument Ltd.) (Yaser et al. 2007). Samples were taken on days 0, 10, 20, 30 and 40 to test the colour of the compost. $10 \mathrm{~g}$ sample was added to $100 \mathrm{~mL}$ distilled water, mixed with magnetic stirrer for $20 \mathrm{~min}$, let stand for $24 \mathrm{~h}$, and then filtered. The absorbance at $\lambda_{\max }=455 \mathrm{~nm}$ was used to analyze colour of the solution with a HACH DR/2010 Spectrophotometer based on HACH DR/2010 Spectrophotometer Procedure Manual from HACH Company, USA, 1996-2000.
The zeta potential of the compost was determined on days $0,10,20,30$ and $40.10 \mathrm{~g}$ sample was added to $100 \mathrm{~mL}$ distilled water, mixed with magnetic stirrer for $20 \mathrm{~min}$, let stand for $24 \mathrm{~h}$ and then filtered. The solution was tested by using a Malvern-Zetasizer Nano Series model ZS machine to determine the zeta potential of the compost.

A germination test was used to evaluate the phytotoxicity of the compost on days 0,20 and 40. The cabbage seeds (Brassica oleracea) were bought from Lian Lee Kimia Sdn. Bhd., Kota Kinabalu, Sabah. The cabbage seeds were soaked in distilled water for $24 \mathrm{~h}$ to determine the initial condition of the seeds. $10 \mathrm{~g}$ of fresh sample and $50 \mathrm{~mL}$ distilled water were mixed to make water-soluble extracts from the compost. Ten cabbage seeds were tested in $5 \mathrm{~mL}$ of water-soluble extracts of compost in petri dishes with a piece of filter paper in darkness at room temperature for 3 days. Another ten cabbage seeds were tested in $5 \mathrm{~mL}$ distilled water with a piece of filter paper as the control (El Fels et al. 2014). The number of germinated seeds was calculated and the growth of roots was recorded after 3 days. The percentage of relative seed germination (RSG), relative root growth (RRG) and germination index (GI) were calculated according to the following formula (Miaomiao et al. 2009):

$\begin{aligned} \text { RSG }(\%)= & \frac{\text { number of seeds germinated in sample extract }}{\text { number of seeds germinated in control }} \\ & \times 100\end{aligned}$

$\mathrm{RRG}(\%)=\frac{\text { root length in sample extract }}{\text { root length in control }} \times 100$

$\mathrm{GI}(\%)=\frac{\mathrm{RSG} \times \mathrm{RRG}}{100}$

\section{Results and discussions}

\section{Temperature profiles}

Figure 3 shows the changes in the compost temperature (T1, T2, T3, T4, T5, and T6) and ambient temperature over 
Fig. 3 Profiles of temperature during composting

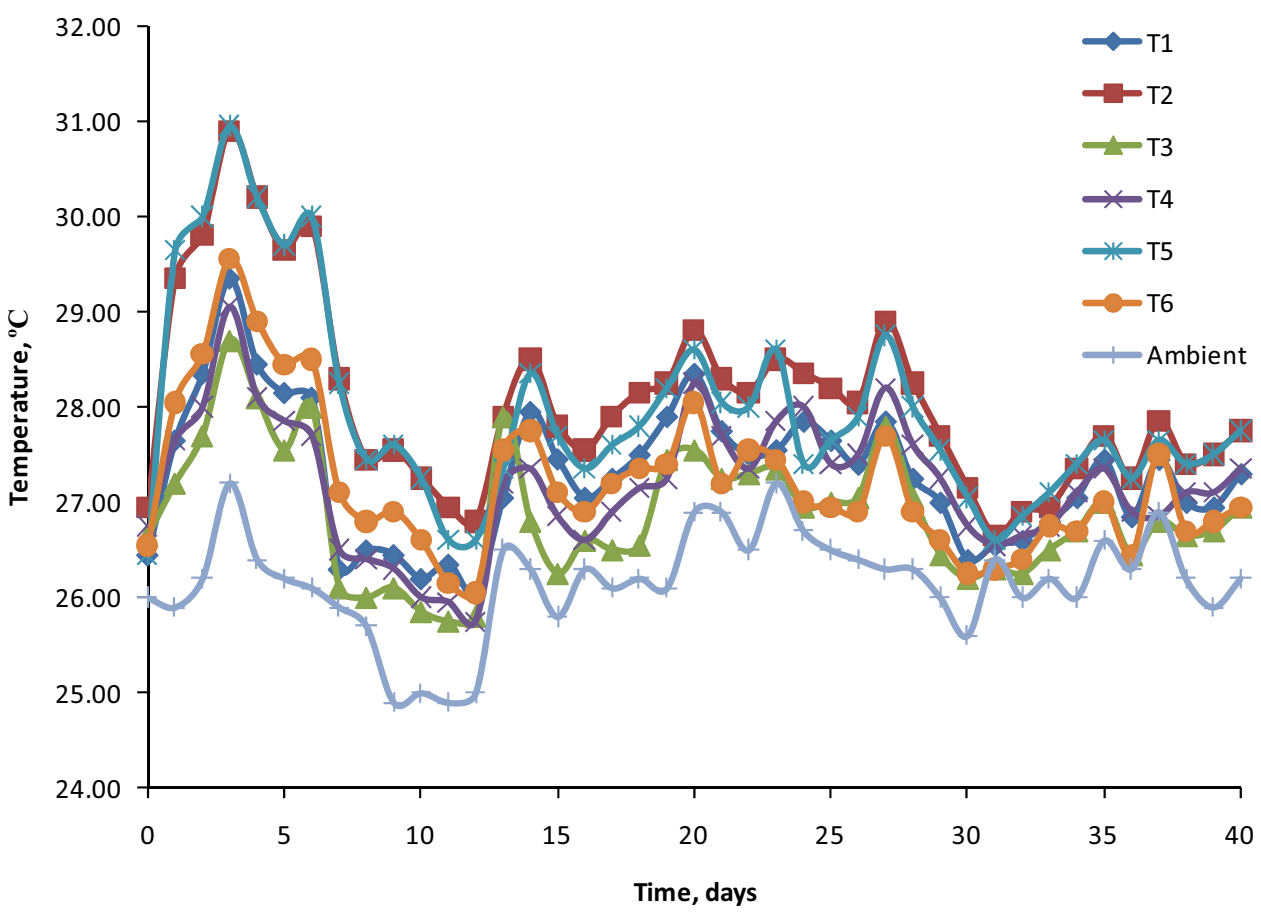

the period of 40 days composting. The profiles of temperature correspond to the stages of composting, microbial activity and microbial group proliferation (Liu and Price 2011). The compost temperatures varied between 25.75 and $30.95^{\circ} \mathrm{C}$, and the ambient temperatures ranged from 24.90 to $27.2^{\circ} \mathrm{C}$. It can be seen that there is a similar pattern in the changes of compost temperature and ambient temperature. The compost temperatures (T2 and $\mathrm{T} 4$ ) showed higher temperature than the others. This might be because of less ventilation in the center of the reactor and thus more heat might be trapped that led to higher temperature. The rise in compost temperatures after the initial peak temperature is due to a renewed increase in the microbial activity (Atagana 2004). At the end of the composting process, the low temperature of the compost indicates that the microbial activity has become weaker.

The compost temperature (T4) reached the highest temperature of $30.95{ }^{\circ} \mathrm{C}$ on day 3 . However, this temperature did not achieve the thermophilic temperature which is about $40-65{ }^{\circ} \mathrm{C}$. Similar results have been reported by Lai et al. (2013), Holmqvist and Stenstrom (2002) and Paradelo et al. (2013). This is most probably due to lack of green waste (Lai et al. 2013; Paradelo et al. 2013) and the small size of reactor (Tang et al. 2007). In addition, it could be caused by the insufficient isolation of the composting material (Paradelo et al. 2013) and the high humidity in the reactor during composting (Lai et al. 2013). As a result, the heat might be easily dissipated during composting thus slowing down the decomposition of organic matter and the emission of nitrogenous products (Lai et al. 2013; Tang et al. 2007).

\section{Moisture content}

A moisture content of $50 \%$ is the minimal requirement for composting (Liang et al. 2003). Figure 4 shows moisture content profiles for this study. As compared to other studies (Kalamdhad and Kazmi 2009; Villegas and Huilinir 2014; Kulcu and Yaldiz 2004), the trend of the moisture content is almost the same; that is, the moisture content decreased slowly as the composting proceeded. In the beginning, the moisture content of the paper-grass clipping-AnPOME compost was $70.35 \%$ and the final compost moisture content obtained was $53.40 \%$. Rapid drop in moisture content, such as this, is due to high heat generation in composting that leads to higher water loss (Kulcu and Yaldiz 2004). In the interval of time: days 10-40, the moisture content of the compost increased to $\sim 56 \%$ due to the lower heat generation. Consequently, the condensed vapor that attached to the back of the reactor's lid fell back into the mixture (Unmar and Mohee 2008).

\section{Mass reduction}

Mass reduction determines the effectiveness of composting as a waste disposal technique (Tang et al. 2007). Figure 5 shows the mass profiles over the study period. In this study, the waste compost gave a mass reduction of $18.29 \%$; which is in the range of other studies (see Table 2). In general, a thermophilic process is believed to accelerate composting. However, based on a study by Arrigoni et al. (2015), a thermophilic process is not a guarantee for higher 


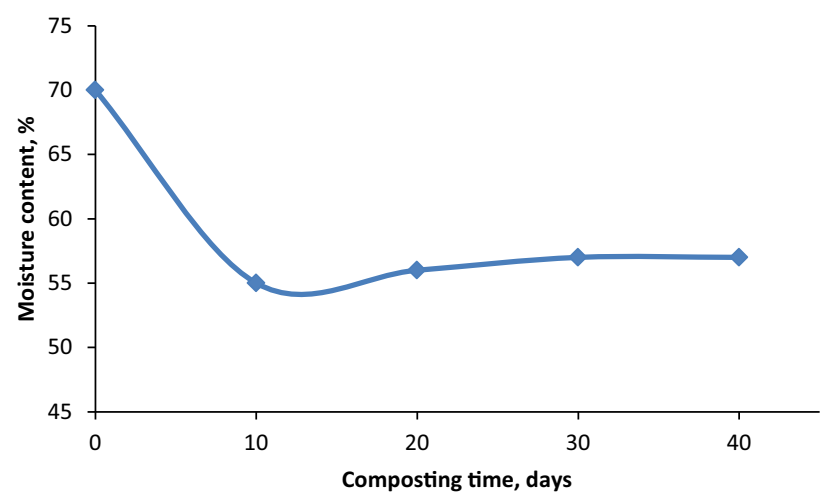

Fig. 4 Moisture content profiles

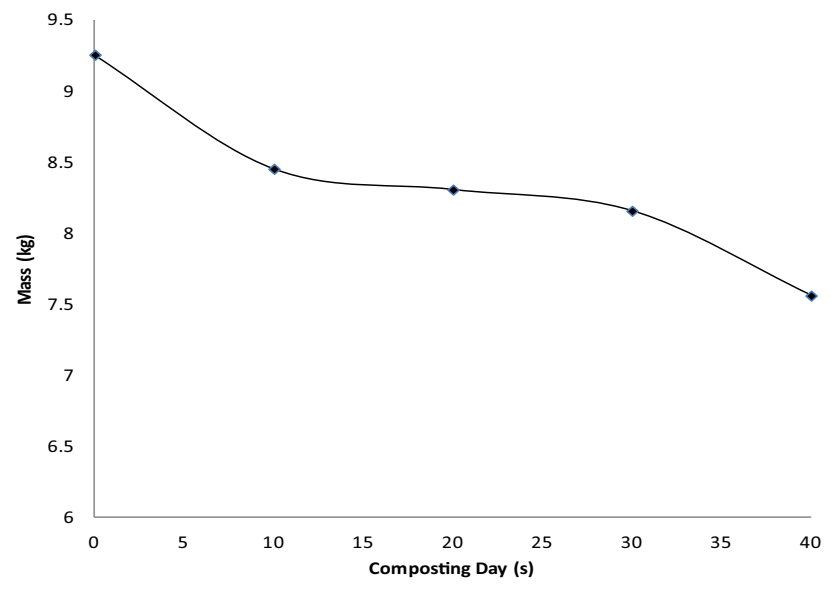

Fig. 5 The change in mass over composting days

mass reduction (see Table 2). The lower mass reductions might be due to the presence of lignin, which is relatively more degradable in aerobic environments but refractory in anaerobic ones (Komilis and Ham 2003). According to Loow et al. (2015), lignin acts as a protective barrier, impermeable and immune to attack from microorganisms and chemical degradation.

\section{Profiles of $\mathrm{pH}$ and conductivity}

Figure 6 shows $\mathrm{pH}$ and electric conductivity against the number of days during the composting process. According to theory, the increase in $\mathrm{pH}$ during the first stage of composting can be attributed to the production of ammonia associated with protein degradation in the samples and to the decomposition of organic acids (Liu et al. 2011), or bioconversion of organic nitrogen into free ammonia (Altieri et al. 2011). Based on this study, the $\mathrm{pH}$ obtained increased slightly from day 0 to day 40 . The highest $\mathrm{pH}$ obtained during the composting was 7.4 and the lowest $\mathrm{pH}$ was 6.95. Based on this study, the trend was for the electrical conductivity to increase during composting. The increase in electrical conductivity is caused by the accumulation of mineral salts as a result of degradation of organic matter (Bustamante et al. 2012).

\section{Colour}

The maturity stage of the compost can be evaluated by the change of color. The change in color of the compost during the composting process reflects the aesthetic quality and potential acceptability of the final compost, which indicates the stabilization of the compost (Mbuligwe et al. 2002). The variation in the colour of compost during the composting period gives an indication of the degree of stabilization of the compost (Mbuligwe et al. 2002). The results showed that after 40 days the color of the compost darkened, which is an indication of stabilization. The changes in color during the composting process might be due to the presence of dissolved and particulate organic matter (Chatterjee et al. 2013). The dark-colored composts lead to higher light absorption and lower reflection rate of light (known as albedo). As a consequence, the dark colored compost will warm up faster due to the higher light absorption as compared to light-colored compost (Fischer and Glaser 2012). Figure 7 indicates the color changes

Table 2 Mass reduction in several composting processes

\begin{tabular}{|c|c|c|c|c|}
\hline Substrate & $\begin{array}{l}\text { Composting } \\
\text { time }\end{array}$ & $\begin{array}{l}\text { Highest temperature } \\
\left({ }^{\circ} \mathrm{C}\right)\end{array}$ & $\begin{array}{l}\text { Mass reduction } \\
(\%)\end{array}$ & References \\
\hline Paper-grass clippings-AnPOME & 40 & 31 & 18 & This study \\
\hline Paper-meat-vegetables & 140 & $50-53$ & $5.5-7.1$ & Arrigoni et al. (2015) \\
\hline Garden waste & 20 & 52 & $40-57$ & Colomer-Mendoza et al. (2012) \\
\hline Domestic waste & 40 & 70 & 78 & Elango et al. (2009) \\
\hline Kitchen waste & 120 & 57 & $59-62$ & $\begin{array}{l}\text { Karnchanawong and Suriyanon } \\
\text { (2011) }\end{array}$ \\
\hline $\begin{array}{l}\text { Biodegradable plastic with green } \\
\text { wastes }\end{array}$ & 56 & 63.3 & 53.2 & Unmar and Mohee (2008) \\
\hline
\end{tabular}


Fig. 6 Profile of $\mathrm{pH}$ and electrical conductivity (EC) during the composting process

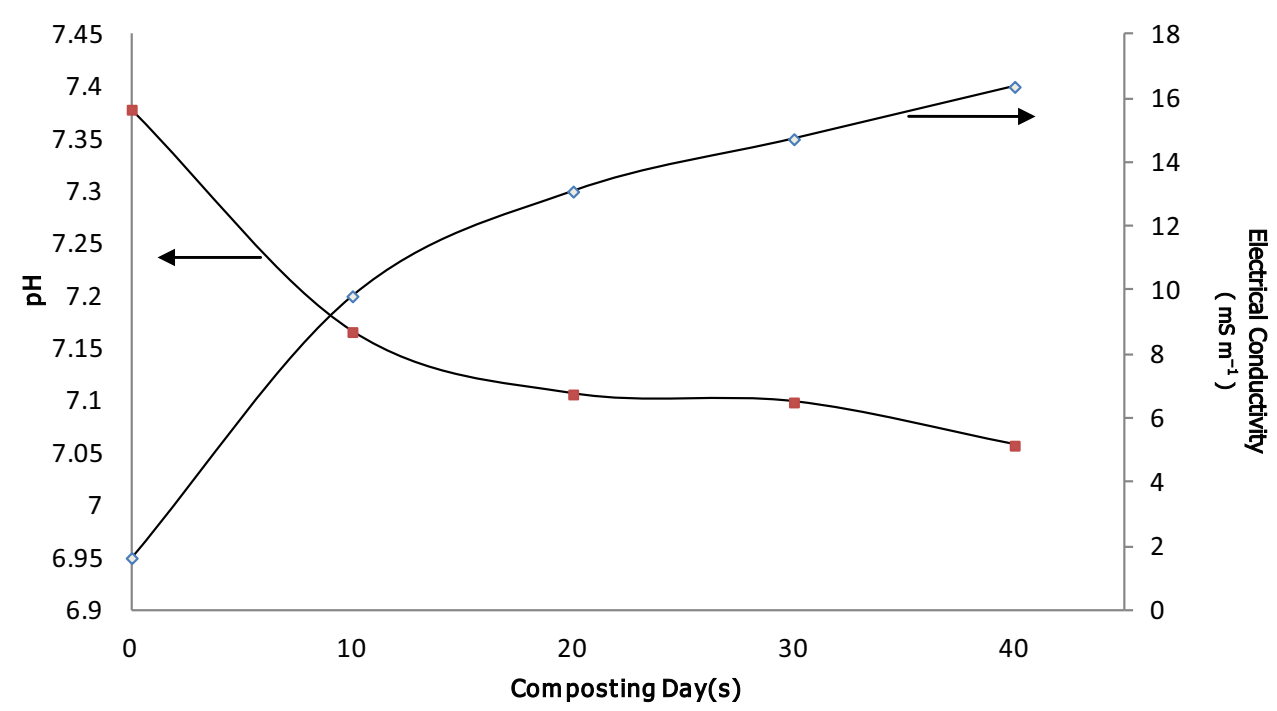

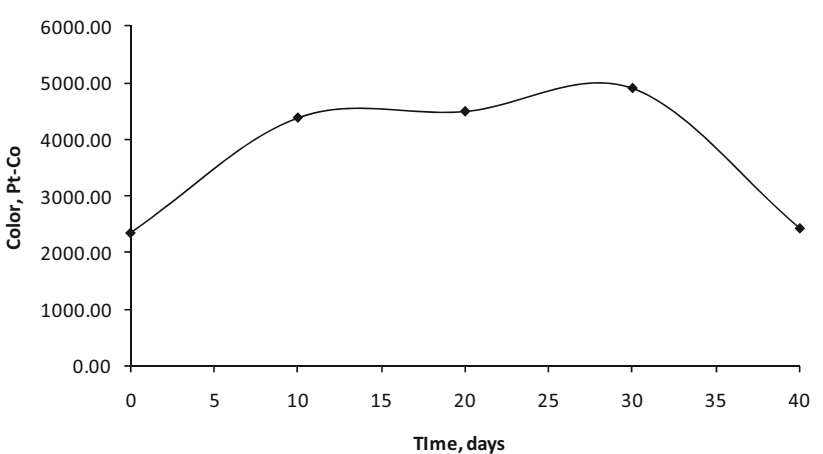

Fig. 7 Changes in color of the compost during composting

during the 40 days of paper-grass clippings-AnPOME composting. With the increase of composting time, the color of compost gradually increased from initial color of $2353 \mathrm{Pt}-\mathrm{Co}$ to maximal $4903 \mathrm{Pt}-\mathrm{Co}$ on day 30 and then decreased to $2434 \mathrm{Pt}-\mathrm{Co}$ at the end of the composting process. However, colour is not suitable as maturity indicator in this study as there is no continuous increase in the colour of the compost as can be observed from the results in Fig. 7.

\section{Zeta potential}

The profiles of zeta potential over the composting period is shown in Fig. 8. Zeta potential can be expressed as the potential difference between the dispersion medium and the stationary layer of fluid attached to the dispersed particles. It indicates the electric potential variation of the residue surface during the decomposition period ( $\mathrm{Li}$ et al. 2014). Surface charge (characterized as zeta potential) is often used to indicate the surface characteristics (Yan et al. 2015). In this study, the results revealed that negative

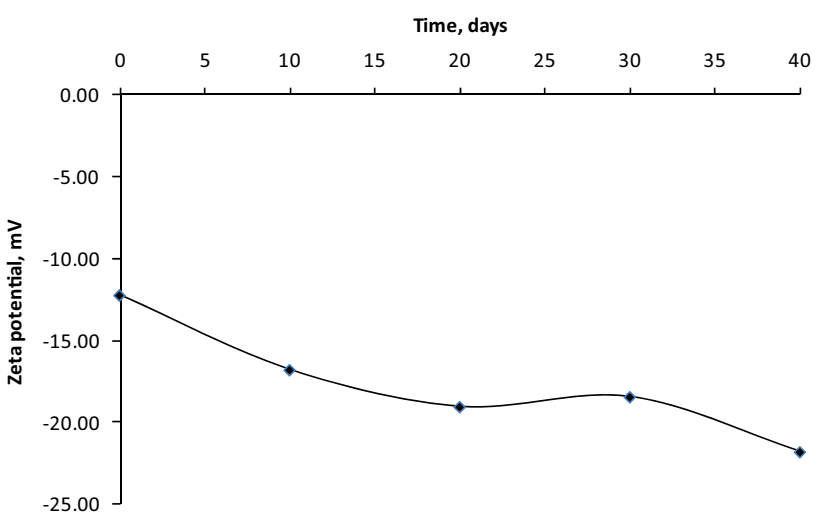

Fig. 8 Profiles of zeta potential during composting

values of zeta potential were obtained in the whole composting process. As composting progressed, the zeta-potential value of the compost decreased gradually from -12.25 to $-19.05 \mathrm{mV}$ in the first 20 days. It can be seen that there was a slight increase on day 30 with a zeta potential value of $-18.05 \mathrm{mV}$. The lowest zeta potential value of $-21.80 \mathrm{mV}$ was observed on the last day of composting. As reported by Zahrim et al. (2014), although the POME is negatively charged from the beginning (i.e., in anaerobic ponds), the POME tends to be more negative in the following treatments i.e., in aerobic ponds, due to the degradation of organic matter.

\section{Phytotoxicity}

The germination index (GI) test is often used to evaluate the compost maturity and phytotoxicity of organic wastes (Miaomiao et al. 2009). Germination index can be indicative that low toxicity is affecting root growth while high toxicity can affect germination (He et al. 2009). The 


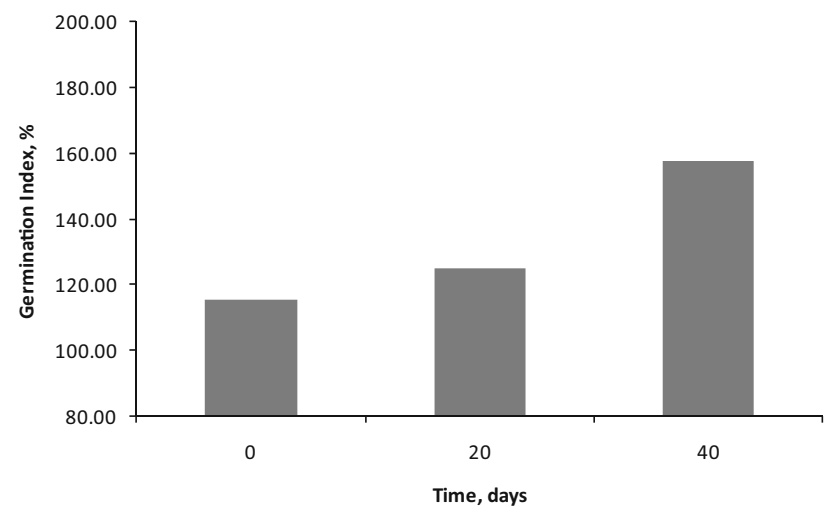

Fig. 9 Profiles of germination index during composting

Table 3 Physicochemical analysis of initial and final compost

\begin{tabular}{|c|c|c|c|}
\hline Composition & $\begin{array}{l}\text { Initial } \\
\text { compost } \\
\text { mixture }\end{array}$ & $\begin{array}{l}\text { Final } \\
\text { compost }\end{array}$ & $\begin{array}{l}\text { Recommended value } \\
\text { for ideal stand-alone substrate }\end{array}$ \\
\hline$C / N$ ratio & 33.39 & 30.93 & $\begin{array}{l}<20 \text { (Jimenes and Garcia 1989; } \\
\text { Yaser et al. 2007) }\end{array}$ \\
\hline $\mathrm{P}_{2} \mathrm{O}_{5}, \%$ & ND & 0.09 & $\begin{array}{l}>0.5 \text { (Nogueira et al. 1999; } \\
\text { Yaser et al. 2007) }\end{array}$ \\
\hline $\mathrm{K}_{2} \mathrm{O}, \%$ & ND & 0.43 & $\begin{array}{l}>1.5 \text { (Nogueira et al. 1999; } \\
\text { Yaser et al. 2007) }\end{array}$ \\
\hline $\mathrm{pH}$ & 7.36 & 7.2 & $\begin{array}{l}\text { 5.5-6.5 (Poole et al. 1981; Yaser } \\
\text { et al. 2007) }\end{array}$ \\
\hline$C, \%$ & 38.4 & 37.19 & - \\
\hline$N, \%$ & 1.15 & 1.20 & - \\
\hline $\mathrm{MgO}, \%$ & ND & 0.20 & - \\
\hline
\end{tabular}

$N D$ not determined

variation of the germination index of the composting process using cabbage seeds (Brassica oleracea) is illustrated in Fig. 9. The results showed that the germination index of the compost had increased gradually with GI values of 115.66, 124.74 and $157.61 \%$ on days 0,20 and 40, respectively. The germination index increased with the age of composting, indicating the decomposition of toxic materials in the composting process (He et al. 2009). These results reflected that phytotoxicity of compost reduced during the composting process and the beneficial effects on Brassica oleracea (cabbage) were more noticeable. The reduction in phytotoxicity is most likely due to the reduction of the fatty substance and soluble phenol content, and also the changes in level of organic acids (PiotrowskaCyplik et al. 2013). In this study, GI content of the compost had exceeded $80 \%$ indicating phytotoxic-free and mature compost (Gao et al. 2010; Gopinathan and Thirumurthy 2012; Guo et al. 2012).

\section{Final nutrients}

Table 3 shows the nutrient data of the final compost in this study that was analyzed by PCM Prestige Central Management Sdn. Bhd. From Table 3, it can be seen that the $\mathrm{pH}$ of the compost is 7.2 which needs to be adjusted before it can be used as a substrate. The $\mathrm{pH}$ value obtained in this study is within the range of other findings i.e., pH 5.6-8.5 (Zahrim and Asis 2010). The compost nutrient content i.e., $\mathrm{N}, \mathrm{P}, \mathrm{K}$ and $\mathrm{Mg}$ (Table 3) is considered to be in the acceptable range and could help the farmers to reduce reliance on inorganic fertilizer and simultaneously improve the soil condition. Application of inorganic fertilizer is costly and could turn the soil more acidic. Also, excessive use of inorganic fertilizers without organic supplements not only deteriorates the physical and chemical properties of the soil but also pollutes the surrounding environment (Lim et al. 2015).

The $C / N$ ratio in this study, i.e., 30.19 , is higher than the recommended value for an ideal substrate. It should be noted that, the further stabilization occurred after application to the soil. It was reported that a $C / N$ of approximately 20 is reported to be phytotoxic-free although the compost is considered as immature (Alam and Ainuddin 2007). A larger amount of grass clippings could be used in the composting to improve $C / N$ ratio of compost by increasing the nitrogen content. The composting time is suggested to be increased so that greater mineralization of organic matter can be achieved.

\section{Conclusions}

In this study, a mixture of paper-grass clippings-AnPOME was decomposed for 40 days. The highest compost temperature $\left(31^{\circ} \mathrm{C}\right)$ was achieved on day 3 of the composting process. The $\mathrm{pH}$ value was increased slightly from 6.95 to 7.4. The electrical conductivity also increased. The moisture content was decreased slightly from 70.35 to $53.40 \%$ while the compost mass reduction was $18.29 \%$. Since the trend of colour (measured as $\mathrm{PtCo}$ ) is not consistent in this study, the colour is not suitable as a maturity indicator. The negative zeta potential values decreased from -12.25 to $-21.80 \mathrm{mV}$ due to organic degradation. The results show that phytotoxicity of compost reduced during the composting process as the germination index increased.

Acknowledgments The authors would like to thank Universiti Malaysia Sabah and British Council Newton Fund (Enhancing environmental resilience and energy security by developing efficient novel methods for converting palm oil waste to biodiesel and fertilizer) for funding this project. 
Open Access This article is distributed under the terms of the Creative Commons Attribution 4.0 International License (http://crea tivecommons.org/licenses/by/4.0/), which permits unrestricted use, distribution, and reproduction in any medium, provided you give appropriate credit to the original author(s) and the source, provide a link to the Creative Commons license, and indicate if changes were made.

\section{References}

Alam Z, Ainuddin M (2007) Bio-composting process development by SSF for utilization agro-industrial wastes. 3rd Kuala Lumpur International Conference on Biomedical Engineering 2006. Springer, Berlin

Altieri R, Esposito A, Nair T (2011) Novel static composting method for bioremediation of olive mill waste. Int Biodeterior Biodegrad 65:786-789

Amira Dayana R, Roshanida AR, Rosli MI, Siti Fatimah Zahrah MF, Mohd Anuar J, Nazrul Adha CM (2011) Bioconversion of empty fruit bunches (EFB) and palm oil mill effluent (POME) into compost using Trichoderma virens. Afr $\mathrm{J}$ Biotechnol 10:18775-18780

Arrigoni JP, Paladino G, Laos F (2015) Feasibility and performance evaluation of different low-tech composter prototypes. Int J Environ Prot 5:1-8

Atagana HI (2004) Co-composting of PAH-contaminated soil with poultry manure. Lett Appl Microbiol 39:163-168

Baishya P, Mahanta DK, Singh SB (2016) Waste composting a sustainable practice. Int J Innov Res Sci Technol 2:537-543

Bala JD, Lalung J, Ismail N (2014) Biodegradation of palm oil mill effluent (POME) by bacterial. Int J Sci Res Publ 4:502-511

Ball AS, Shah D, Wheatley CF (2000) Assessment of the potential of a novel newspaper/horse manure-based compost. Bioresour Technol 73:163-167

Bustamante MA, Alburquerque JA, Restrepo AP, de la Fuente C, Paredes C, Moral R, Bernal MP (2012) Co-composting of the solid fraction of anaerobic digestates, to obtain added-value materials for use in agriculture. Biomass Bioenergy 43:26-35

Chatterjee N, Flury M, Hinman C, Craig G (2013) Chemical and physical characteristics of compost leachates-a review. Department of Crop and Soil Sciences, Washington State University, Puyallup

Colomer-Mendoza FJ, Herrera-Prats L, Robles-Martinez F, GallardoIzquierdo A, Pina-Guzman AB (2012) Effect of airflow on biodrying of gardening wastes in reactors. $\mathrm{J}$ Environ Sci $25: 865-872$

el Fels L, Zamama M, el Asli A, Hafidi M (2014) Assessment of biotransformation of organic matter during co-composting of sewage sludge-lignocelullosic waste by chemical, FTIR analyses, and phytotoxicity tests. Int Biodeterior Biodegrad $87: 128-137$

Elango D, Thinakaran N, Panneerselvam P, Sivanesan S (2009) Thermophilic composting of municipal solid waste. Appl Energy 86:663-668

Elouaqoudi FZ, el Fels L, Amir S, Merlina G, Meddich A, Lemee L, Ambles A, Hafidi M (2015) Lipid signature of the microbial community structure during composting of date palm waste alone or mixed with couch grass clippings. Int Biodeterior Biodegrad 97:75-84

Fischer D, Glaser B (2012) Synergisms between compost and biochar for sustainable soil amelioration. INTECH Open Access Publisher, Rijeka

Francou CD, Linãres M, Derenne S, Villio-Poitrenaud ML, Houot S (2008) Influence of green waste, biowaste and paper-cardboard initial ratios on organic matter transformations during composting. Bioresour Technol 99:8926-8934

Gao M, Li B, Yu A, Liang F, Yang L, Sun Y (2010) The effect of aeration rate on forced-aeration composting of chicken manure and sawdust. Bioresour Technol 101:1899-1903

Gopinathan M, Thirumurthy M (2012) Evaluation of phytotoxicity for compost from organic fraction of municipal solid waste and paper \& pulp mill sludge. Environ Res Eng Manag 59:47-51

Guo R, Li G, Jiang T, Schuchardt F, Chen T, Zhao Y, Shen Y (2012) Effect of aeration rate, $\mathrm{C} / \mathrm{N}$ ratio and moisture content on the stability and maturity of compost. Bioresour Technol 112:171-178

He M, Tian G, Liang X (2009) Phytotoxicity and speciation of copper, zinc and lead during the aerobic composting of sewage sludge. J Hazard Mater 163:671-677

Hoe TK, Sarmidi MR, Alwee SSRS, Zakaria ZA (2016) Recycling of oil palm empty fruit bunch as potential carrier for biofertilizer formulation. J Teknol 78:165-170

Holmqvist A, Stenstrom TA (2002) Survival of Ascaris suum ova, indicator bacteria and Salmonella typhimurium phage $28 \mathrm{~B}$ in mesophilic composting of household waste. In: Abstract volume, first international conference on ecological sanitation

Jimenes E, Garcia V (1989) Evaluation of city refuse compost maturity. Biol Wastes 3:115-142

Juchelkova D, Corsaro A, Hlavsova A, Raclavska H (2015) Effect of composting on the production of syngas during pyrolysis of perennial grasses. Fuel 154:380-390

Kalamdhad AS, Kazmi AA (2009) Effects of turning frequency on compost stability and some chemical characteristics in a rotary drum composter. Chemosphere 74:1327-1334

Karnchanawong S, Suriyanon N (2011) Household organic waste composting using bins with different types of passive aeration. Resour Conserv Recycl 55:548-553

Komilis DP, Ham RK (2003) The effect of lignin and sugars to the aerobic decomposition of solid wastes. Waste Manag 23:419-423

Kulcu R, Yaldiz O (2004) Determination of aeration rate and kinetics of composting some agricultural wastes. Bioresour Technol 93:49-57

Lai JC, Chua HB, Saptoro A, Ang HM (2013) Effect of isolated mesophilic bacterial consortium on the composting process of pressed-shredded empty oil palm fruit bunch. In: Ravindra P, Bono A, Chu C (eds) Developments in sustainable chemical and bioprocess technology. Springer, Berlin

Li J, Lu J, Li X, Ren T, Cong R, Zhou L (2014) Dynamics of potassium release and adsorption on rice straw residue. PLoS One 9:e90440

Liang C, Das KC, McClendon RW (2003) The influence of temperature and moisture contents regimes on the aerobic microbial activity of a biosolids composting blend. Bioresour Technol 86:131-137

Lim SL, Wu TY, Lim PN, Shak KPY (2015) The use of vermicompost in organic farming: overview, effects on soil and economics. J Sci Food Agric 95:1143-1156

Lim SL, Lee LH, Wu TY (2016) Sustainability of using composting and vermicomposting technologies for organic solid waste biotransformation: recent overview, greenhouse gases emissions and economic analysis. J Clean Prod 111:262-278

Liu K, Price GW (2011) Evaluation of three composting systems for the management of spent coffee grounds. Bioresour Technol 102:7966-7974

Liu D, Zhang R, Wu H, Xu D, Tang Z, Yu G, Xu Z, Shen Q (2011) Changes in biochemical and microbiological parameters during the period of rapid composting of dairy manure with rice chaff. Bioresour Technol 102:9040-9049

Loow YL, Wu TY, Tan KA, Lim YS, Siow LF, MD. Jahim J, Mohammad AW, Teoh WH (2015) Recent advances in the 
application of inorganic salt pretreatment for transforming lignocellulosic biomass into reducing sugars. J Agric Food Chem 63:8349-8363

Mbuligwe SE, Kassenga GR, Kaseva ME, Chaggu EJ (2002) Potential and constraints of composting domestic solid waste in developing countries: findings from a pilot study in Dar es Salaam, Tanzania. Resour Conserv Recycl 36:45-59

Miaomiao H, Wenhong L, Xinqiang L, Donglei W, Guangming T (2009) Effect of composting process on phytotoxicity and speciation of copper, zinc and lead in sewage sludge and swine manure. Waste Manag 29:590-597

Moh YC, Manaf LA (2014) Overview of household solid waste recycling policy status and challenges in Malaysia. Resour Conserv Recycl 82:50-61

Nogueira W, Nogueira F, Devens D (1999) Temperature and $\mathrm{pH}$ control in composting of coffee and agricultural wastes. Water Sci Technol 40:113-119

Palaniappan S (1993) Leaching losses and nutrient build-up in the soil through application of raw and digested palm oil mill effluent (POME). Pertanika J Trop Agric Sci 16:25-29

Paradelo R, Moldes AB, Barral MT (2013) Evolution of organic matter during the mesophilic composting of lignocellulosic winery wastes. J Environ Manage 116:18-26

Petric I, Helic A, Avdic EA (2012) Evolution of process parameters and determination of kinetics for co-composting of organic fraction of municipal solid waste with poultry manure. Bioresour Technol 117:107-116

Piotrowska-Cyplik A, Chrzanowski L, Cyplik P, Dach J, Olejnik A, Staninska J, Czarny J, Lewicki A, Marecik R, Powierska-Czarny J (2013) Composting of oiled bleaching earth: fatty acids degradation, phytotoxicity and mutagenicity changes. Int Biodeterior Biodegrad 78:49-57

Poole R, Conover C, Joiner J (1981) Soils and potting mixtures. In: Jointer JN (ed) Foliage plant production. Englewood Cliffs, New Jersey, pp 179-202

Siang PC, Zakaria R (2006) Investigation on combustion characteristics of municipal solid waste from Penang State Malaysia. 4th i-CIPEC, Kyoto, Japan

Tabassum S, Zhang Y, Zhang Z (2015) An integrated method for palm oil mill effluent (POME) treatment for achieving zero liquid discharge-A pilot study. J Clean Prod 95:148-155

Tang J-C, Shibata A, Zhou Q, Katayama A (2007) Effect of temperature on reaction rate and microbial community in composting of cattle manure with rice straw. J Biosci Bioeng 104:321-328

Traversa A, Loifredo E, Palazzo A, Bashore T, Senesi N (2014) Enhancement of switchgrass (Panicum virgatum 1.) early growth as affected by composts. J Soil Sci Plant Nutr 14:471-482

Unmar G, Mohee R (2008) Assessing the effect of biodegradable and degradable plastics on the composting of green wastes and compost quality. Bioresour Technol 99:6738-6744

Villegas M, Huilinir C (2014) Biodrying of sewage sludge: kinetics of volatile solids degradation under different initial moisture contents and air-flow rates. Bioresour Technol 174:33-41

Wu TY, Lim SL, Lim PN, Shak KPY (2014) Biotransformation of biodegradable solid wastes into organic fertilizers using composting or/and vermicomposting. Chem Eng Trans 39:1579-1584

Xiao Y, Zeng G-M, Yang Z-H, Shi W-J, Huang C, Fan C-Z, Xu Z-Y (2009) Continuous thermophilic composting (CTC) for rapid biodegradation and maturation of organic municipal solid waste. Bioresour Technol 100:4807-4813

Yan L, Liu Y, Wen Y, Ren Y, Hao G, Zhang Y (2015) Role and significance of extracellular polymeric substances from granular sludge for simultaneous removal of organic matter and ammonia nitrogen. Bioresour Technol 179:460-466

Yaser AZ, Abd RR, Kalil MS (2007) Co-composting of palm oil mill sludge-sawdust. Pak J Biol Sci 10:4473-4478

Yaser AZ, Nurmin B, Rosalam S (2013) Coagulation/flocculation of Anaerobically Treated Palm Oil Mill Effluent (AnPOME): a review. In: Ravindra P, Bono A, Ming CC (eds) Developments in sustainable chemical and bioprocess technology. Springer, New York

Zahrim AY, Asis T (2010) Production of non shredded empty fruit bunch semi-compost. The Institution of Engineers, Malaysia 71:4

Zahrim AY (2014) Palm oil mill biogas producing process effluent treatment: a short review. J Appl Sci 14:3149-3155

Zahrim AY, Nasimah A, Hilal N (2014) Pollutants analysis during conventional palm oil mill effluent (POME) ponding system and decolourisation of anaerobically treated POME via calcium lactate-polyacrylamide. J Water Process Eng 4:159-165

Zahrim AY, Asis T, Hashim MA, Al-Mizi TMTMA, Ravindra P (2015) A review on the empty fruit bunch composting: life cycle analysis and the effect of amendment(s). In: Ravindra P (ed) Advances in bioprocess technology. Springer, Berlin 